\title{
Au(I)-Catalyzed Enantioselective Synthesis of Functionalized Indenes
}

\author{
Alberto Martínez, ${ }^{[a]}$ Patricia García-García, ${ }^{[a]}$ Manuel A. Fernández-Rodríguez, ${ }^{[a]}$ Félix \\ Rodríguez, ${ }^{[b]}$ Roberto Sanz ${ }^{*[a]}$
}

Molecules containing the $1 H$-indene scaffold show a wide range of biological activities, ${ }^{[1]}$ and possess great interest as functional materials, ${ }^{[2]}$ as well as precursors of metallocene complexes as for catalytic polymerization processes. $^{[3]}$ So, several methodologies have been developed for their synthesis. ${ }^{[4]}$ Despite the unquestionable interest of optically active indenes bearing the $\mathrm{C}-1$ as stereogenic center, as far as we know, only two closely related strategies for the enantioselective synthesis of these compounds from achiral substrates have been published. ${ }^{[5-8]}$ Both of them are based on the use of boronic acid derivatives as starting materials and dicationic Pd(II) complexes as catalyst. Thus, enantioenriched 1arylindenes have been obtained in a cascade 1,4-addition-aldol condensation process, ${ }^{[5]}$ whereas $1 \mathrm{H}$-indenes bearing a $\mathrm{CH}_{2} \mathrm{COR}$ group at the $\mathrm{C}-1$ position are formed from ortho-boronate substituted cinnamic ketones and internal alkynes. ${ }^{[6,7]}$ The scarcity of general methods for the synthesis of optically active indenes (in particular from achiral substrates) aimed us to initiate a project in this field. Our premise was the use of easily available starting materials and, therefore, we fixed our attention on the catalytic cyclization of ortho-(alkynyl)styrenes. In this context, it should be taken into consideration that the skeletal rearrangement of ortho(alkynyl)styrenes catalyzed by several metallic complexes has been described to afford naphthalene derivatives through a 6-endo cyclization process (Scheme 1, eq. 1). ${ }^{[9-13]}$ However, a careful examination of all these publications showed that reactions with $o$ (alkynyl)styrenes where the terminal carbon of the alkene was disubstituted were not reported. So, we envisaged that $o$ (alkynyl)styrenes possessing a highly substituted alkene moiety and an internal acetylene could favour the 5-endo reaction pathway, due to a better stabilization of the exocyclic carbocationic intermediate, to form the desired indene skeleton with a stereogenic center at C-1 (Scheme 1, eq. 2). ${ }^{[14]}$ Herein we report our success on this unprecedented metal-catalyzed 5-endo-dig cyclization of $o$ (alkynyl)styrenes and the application of this reaction in the synthesis

[a] A. Martínez, Dr. P. García-García, Dr. M. A. FernándezRodríguez, Dr. R. Sanz

Área de Química Orgánica, Departamento de Química

Facultad de Ciencias, Universidad de Burgos

Pza. Misael Bañuelos s/n, 09001-Burgos (Spain)

Fax: (+34) 947-258831

E-mail: rsd@ubu.es

Homepage:http://www.ubu.es/paginas/grupos_investigacio n/cien_biotec/sintorg/uk/index.htm

[b] Dr. F. Rodríguez

Instituto Universitario de Química Organometálica "Enrique Moles", Universidad de Oviedo

C/Julián Clavería, 8, 33006, Oviedo (Spain)

[**] We are grateful to MEC/FEDER (CTQ2007-61436/BQU, FPU grant to A.M., Ramón y Cajal and Juan de la Cierva contracts to M.A.F.-R. and P.G.-G.), and Junta de Castilla y León (BU021A09) for the financial support. We also thank Dr. A. Mendoza (Universidad de Oviedo) for his assistance with the X-ray crystallographic analysis.

Supporting information for this article is available on the WWW under http://www.angewandte.org or from the author of enantiomerically-enriched indenes.

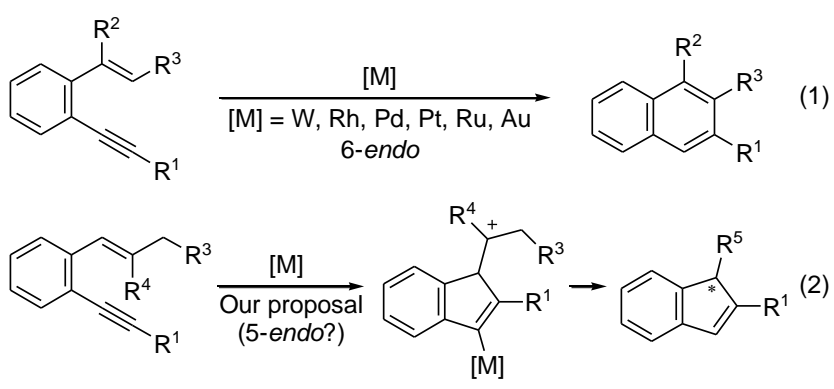

Scheme 1. Skeletal rearrangement of ortho-(alkynyl)styrenes. Previous work and proposed pathway.

For the initial assays we selected $2^{\prime}, 2^{\prime}$-dimethyl o(phenylethynyl)styrene 1a as a model substrate (Scheme 2). Due to their excellent ability to activate alkynes, ${ }^{[15]}$ several complexes derived from coinage metals and platinum were tested as catalysts for the desired transformation. However, no reaction was observed with metal complexes such us $\mathrm{AgSbF}_{6}, \mathrm{PtCl}_{2},\left[\mathrm{PtCl}_{2}(\mathrm{cod})\right], \mathrm{CuI}$, $\mathrm{AuCl}_{3}, \mathrm{AuCl}$ or $\left[\mathrm{AuCl}\left(\mathrm{Ph}_{3} \mathrm{P}\right)\right]$. Encouragingly, the reaction proceeded to completion within $30 \mathrm{~min}$ to yield the indenyl derivative 2a in a high isolated yield (88\%), when it was performed in dichloromethane at room temperature in the presence of the cationic gold(I) complex generated in situ from $5 \mathrm{~mol} \%$ of $\left[\mathrm{AuCl}\left(\mathrm{Ph}_{3} \mathrm{P}\right)\right]$ and $5 \mathrm{~mol} \%$ of $\mathrm{AgSbF}_{6} \cdot{ }^{[16]}$ Moreover, when this reaction was conducted in the presence of 5 equivalents of methanol we observed the formation of compound 3aa in excellent yield (90\%) (Scheme 2). The high selectivity of these reactions should be remarked as we did not observe the formation of naphthalene derivatives coming from a 6-endo-dig type cyclization or any other product coming from 5-exo additions of the alkene to the triple bond.

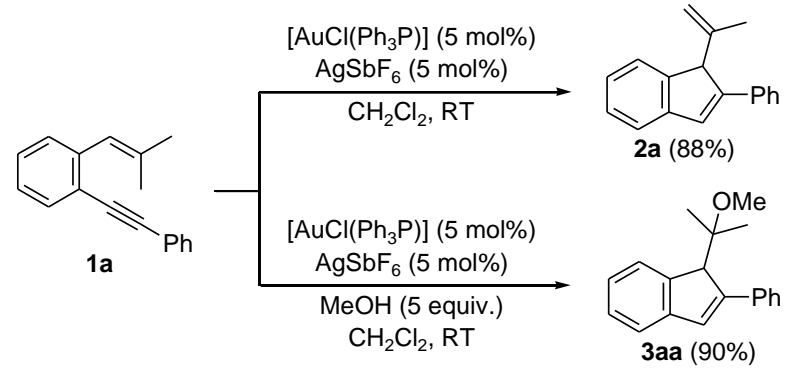

Scheme 2. Initial experiments. Proof of concept.

A catalytic cycle that explains the formation of indenes 2a and 3aa is shown in Scheme $3 .^{[17]}$ The reaction is initiated by coordination of the cationic gold complex to the triple bond of the starting $o$-(alkynyl)styrene 1a to give intermediate 4. Intramolecular addition of the alkene moiety selectively leads to the cationic intermediate $\mathbf{5}$, which can be represented as the two resonance structures $\mathbf{5 a}$ and $\mathbf{5 b}$, through a 5-endo-dig cyclization as we 
anticipated. Elimination of a proton in $\mathbf{5}$ (path a) furnishes the vinylgold intermediate $\mathbf{6}$, which after a protodemetalation reaction gives the indene 2a. Alternatively, in the presence of methanol, trapping of the carbocation $\mathbf{5 a}$ or a nucleophilic attack on $\mathbf{5 b}$ accounts for the formation of vinyl-gold intermediate 7. Further protodemetalation furnishes compound 3aa regenerating the catalytic species.

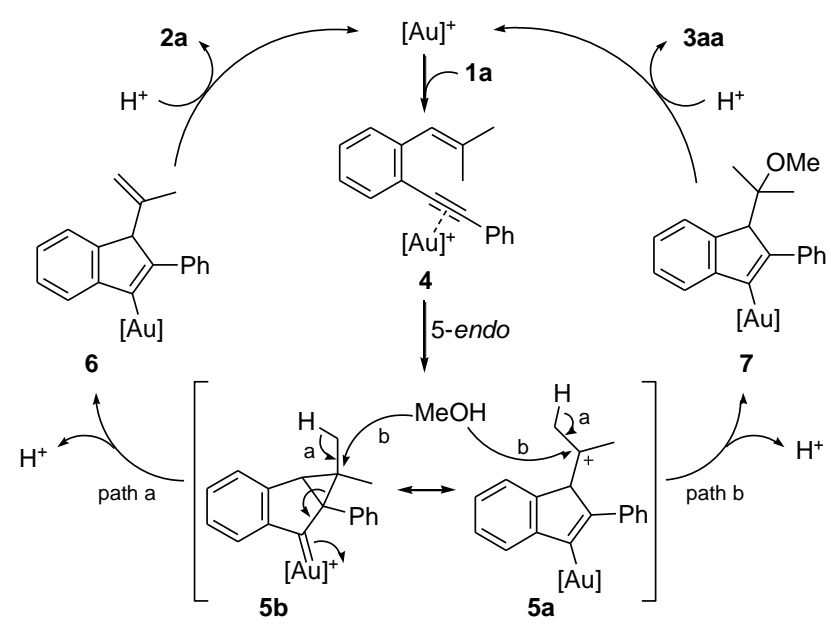

Scheme 3. Proposed mechanisms for the synthesis of indenes.

To support the proposed mechanism we performed the labelling experiment shown in Scheme 4. Thus, when compound 1a was reacted in the presence of 5 equivalents of $\mathrm{D}_{2} \mathrm{O}$ under the catalytic conditions previously commented we observed the exclusive formation of the deuterated compound 3ab-D in $89 \%$ yield $(92 \%$ deuterium incorporation at C-3). Interestingly, this experiment also served to demonstrate that water could be used as nucleophilic partner in this new reaction.

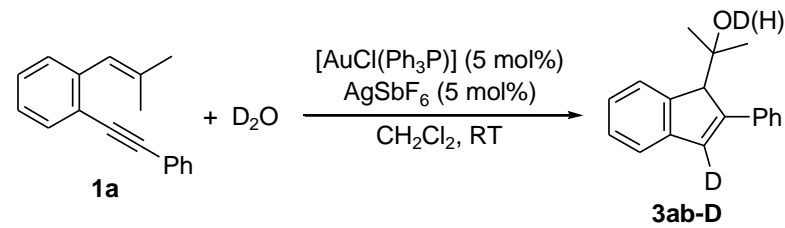

(89\% yield; $92 \% \mathrm{D}$ at C-3)

Scheme 4. Labelling experiment.

Once we had demonstrated the feasibility of our method for the preparation of indenes through a gold-catalyzed 5-endo-dig cyclization, ${ }^{[18]}$ we faced our original goal, the control of the C-1 stereogenic center. In this context it should be noted that despite the use of gold in homogeneous catalysis has witnessed tremendous activity in recent years, asymmetric gold-catalyzed reactions are still scarce. ${ }^{[19]}$ Most of these stereoselective processes are related to the enantioselective $\pi$-activation of allenes ${ }^{[20]}$ and very few examples have been reported about asymmetric gold-catalyzed processes involving alkyne activation. ${ }^{[21]}$ To the best of our knowledge, no examples have been reported about the enantioselective cycloisomerization or alkoxycyclization of $o$-(alkynyl)styrenes. ${ }^{[22]}$

Taking into account the relative success on the use of chiral biphosphines with biphenyl skeletons as ligands in gold-catalyzed enantioselective reactions, we prepared several dinuclear chiral gold(I) catalysts with $(R)$-BINAP (L1), $(S)$ - $\mathrm{H}_{8}$-BINAP (L2), $(S)$ SEGPHOS (L3), (S)-3,5-xylyl-SEGPHOS $\quad(\mathbf{L 4}), \quad(S)$-DTBM-
SEGPHOS (L5), MeOBIPHEP (L6), (S)-3,5-xylyl-MeOBIPHEP (L7), and (S)-DTBM-MeOBIPHEP (L8) as ligands (Figure 1), according to known procedures. ${ }^{[21 \mathrm{a}}$
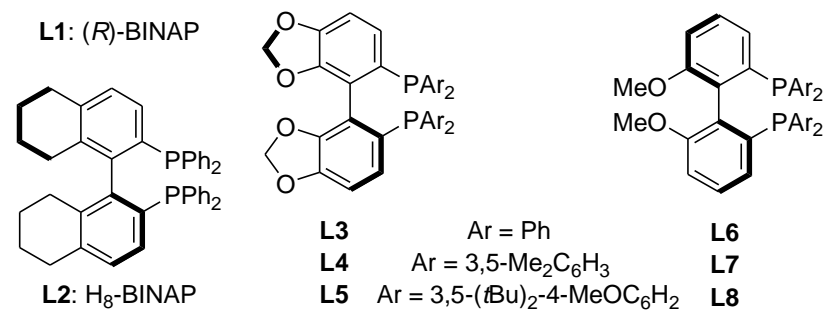

Figure 1. Chiral ligands (L1-L8) screened in the gold(I)-catalyzed enantioselective cycloisomerization of o-(alkynyl)styrenes 1.

Initial efforts were focused on the optimization of an efficient chiral catalyst for the transformation of $o$-(alkynyl)styrene 1a into 1alkenyl- $1 H$-indene 2a (Table 1 ). We were pleased to find that the use of all tested chiral gold complexes associated with the silver salt $\mathrm{AgSbF}_{6}$ allowed completed conversions in one hour at room temperature (entries 1-8). The best result regarding the enantiomeric excess was found by using the gold complex bearing the ligand 3,5xylyl-MeOBIPHEP (L7) (entry 7). So, further optimization was performed with this complex. The influence of the silver salt was then investigated (entries 7, 9, 10), silver tosylate giving the best result. Finally, by lowering the temperature to $-30^{\circ} \mathrm{C}$ we were able to obtain the indene $\mathbf{2 a}$ with a pleasant $82 \%$ enantiomeric excess in a reasonable reaction time (entries 10-13). At lower temperature only a slight improvement in the enantioselectivity was observed, while the reaction became sluggish (entry 14).

Table 1: Optimization of the reaction conditions for the asymmetric synthesis of indene $\mathbf{2} a^{[a]}$

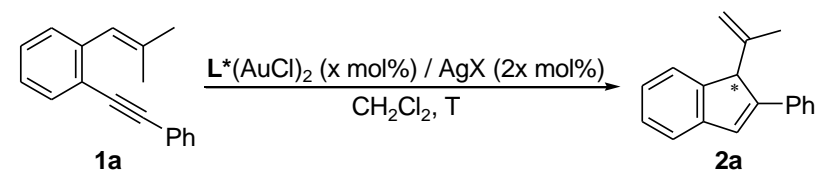

\begin{tabular}{|c|c|c|c|c|c|}
\hline Entry & $L^{*} / \mathrm{AgX}$ & x mol\% & $\mathrm{T}\left[{ }^{\circ} \mathrm{C}\right]$ & $t[\mathrm{~h}]$ & ee $[\%]^{[b]}$ \\
\hline 1 & L1 / $\mathrm{AgSbF}_{6}$ & 2.5 & 25 & 1 & -10 \\
\hline 2 & $\mathrm{~L}^{2} / \mathrm{AgSbF}_{6}$ & 2.5 & 25 & 1 & 35 \\
\hline 3 & L3 / $\mathrm{AgSbF}_{6}$ & 2.5 & 25 & 1 & 24 \\
\hline 4 & $\mathrm{~L}^{4} / \mathrm{AgSbF}_{6}$ & 2.5 & 25 & 1 & 40 \\
\hline 5 & L5 / $\mathrm{AgSbF}_{6}$ & 2.5 & 25 & 1 & 24 \\
\hline 6 & L6 / $\mathrm{AgSbF}_{6}$ & 2.5 & 25 & 1 & 36 \\
\hline 7 & L7 / $\mathrm{AgSbF}_{6}$ & 2.5 & 25 & 1 & 41 \\
\hline 8 & $\mathbf{L 8} / \mathrm{AgSbF}_{6}$ & 2.5 & 25 & 1 & 29 \\
\hline 9 & L7 / AgOTf & 2.5 & 25 & 3 & 50 \\
\hline 10 & L7 / AgOTs & 2.5 & 25 & 6 & 60 \\
\hline 11 & L7 / AgOTs & 5 & 0 & 24 & 70 \\
\hline 12 & L7 / AgOTs & 5 & -20 & 48 & 76 \\
\hline 13 & L7 / AgOTs & 5 & -30 & 80 & 82 \\
\hline 14 & L7 / AgOTs & 5 & -40 & 120 & $85^{\lfloor c\rfloor}$ \\
\hline
\end{tabular}

[a] Reactions conducted using $0.05 \mathrm{mmol}$ of $2^{\prime}, 2^{\prime}$-dimethyl $o$ (phenylethynyl)styrene 1a, in $\mathrm{CH}_{2} \mathrm{Cl}_{2}(0.2 \mathrm{~mL})$ until complete conversion. [b] Determined by HPLC analysis (column: Chiralcel-OJ, eluent: hexane $/ \mathrm{PrOH}$ 90:10, flow: $1 \mathrm{mLmin}^{-1}$. [c] 77\% conversion as estimated by ${ }^{1} \mathrm{H}-\mathrm{NMR}$.

Under the optimized catalytic conditions, the use of $(S)-3,5-$ xylyl-MeOBIPHEP- $(\mathrm{AuCl})_{2}$ associated with silver salt AgOTs in $\mathrm{CH}_{2} \mathrm{Cl}_{2}$, we examined the scope of this enantioselective reaction (Table 2). As shown, the reaction is tolerant towards a variety of $o$ (alkynyl)styrenes $\mathbf{1}$ bearing different substituents at the aromatic ring $\left(\mathrm{R}^{1}, \mathrm{R}^{2}\right)$, at the alkene terminal carbon $\left(\mathrm{R}^{3}, \mathrm{R}^{4}\right)$, and at the 
alkyne moiety $\left(\mathrm{R}^{5}\right)$. High yields and enantioselectivities were observed for starting materials 1a-f where $\mathrm{R}^{5}$ is an aromatic or heteroaromatic group (entries 1-6). However, for alkyl-substituted alkyne (1g) a lower enantioselectivity was observed (entry 7). In addition, the possibility of increasing the enantiomeric excess of the final products by a simple recrystallization has been demonstrated (entry 5).

Table 2. Gold(I)-catalyzed enantioselective synthesis of 1 -alkenyl-1 $H$ indenes $2^{[a]}$
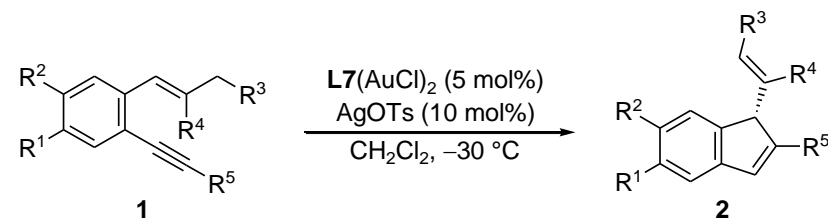

\begin{tabular}{llllllllll}
\hline Entry & $\mathbf{1}$ & $\mathrm{R}^{1}$ & $\mathrm{R}^{2}$ & $\mathrm{R}^{3}$ & $\mathrm{R}^{4}$ & $\mathrm{R}^{5}$ & $\mathbf{2}$ & $\begin{array}{c}\text { Yield } \\
{[\%]^{[\mathrm{b}]}}\end{array}$ & $\begin{array}{l}\text { ee } \\
{[\%]^{[\mathrm{c}]}}\end{array}$ \\
\hline 1 & $\mathbf{1 a}$ & $\mathrm{H}$ & $\mathrm{H}$ & $\mathrm{H}$ & $\mathrm{Me}$ & $\mathrm{Ph}$ & $\mathbf{2 a}$ & 81 & 82 \\
$2^{[\mathrm{d}]}$ & $\mathbf{1 b}$ & $\mathrm{H}$ & $\mathrm{F}$ & $\mathrm{H}$ & $\mathrm{Me}$ & $\mathrm{Ph}$ & $\mathbf{2 b}$ & 84 & 77 \\
$3^{[\mathrm{d}]}$ & $\mathbf{1 c}$ & $-\mathrm{OCH}_{2} \mathrm{O}-$ & $\mathrm{H}$ & $\mathrm{Me}$ & $\mathrm{Ph}$ & $\mathbf{2 c}$ & 84 & 86 \\
4 & $\mathbf{1 d}$ & $\mathrm{H}$ & $\mathrm{H}$ & $-\left(\mathrm{CH}_{2}\right)_{3}$ & $\mathrm{Ph}$ & $\mathbf{2 d}$ & 93 & 81 \\
5 & $\mathbf{1 e}$ & $\mathrm{H}$ & $\mathrm{H}$ & $-\left(\mathrm{CH}_{2}\right)_{4^{-}}$ & $\mathrm{Ph}$ & $\mathbf{2 e}$ & 96 & $80(92)$ \\
6 & $\mathbf{1 f}$ & $\mathrm{H}$ & $\mathrm{H}$ & $\mathrm{H}$ & $\mathrm{Me}$ & $3-\mathrm{Th} h^{[\mathrm{e}]}$ & $\mathbf{2 f}$ & 81 & 68 \\
$7^{[\mathrm{d}]}$ & $\mathbf{1 g}$ & $\mathrm{H}$ & $\mathrm{H}$ & $\mathrm{H}$ & $\mathrm{Me}$ & $n-\mathrm{Bu}$ & $\mathbf{2 g}$ & 80 & 20 \\
\hline
\end{tabular}

[a] Reactions conducted using $0.3 \mathrm{mmol}$ of $o$-(alkynyl)styrene derivative 1 in $\mathrm{CH}_{2} \mathrm{Cl}_{2}(0.6 \mathrm{~mL})$ at $-30{ }^{\circ} \mathrm{C}$ for 3-4 days. [b] Yield of isolated product based on starting material 1. [c] Determined by HPLC analysis, see Supporting Information; in brackets ee after recrystallization. [d] Reaction conducted at $-20{ }^{\circ} \mathrm{C}$. [e] 3-Thienyl.

We have also examined the enantioselective alkoxycyclization of o-(alkynyl)styrenes 1 (Table 3). Again, high yields and enantioselectivities were observed for aryl-substituted alkynes 1a$\mathbf{f}, \mathbf{h}$ in the presence of several alcohols (entries 1, 3-6, 8, 10, 12, and 16) or water (entries $2,7,9,11,13$, and 17). Primary and secondary alcohols, as well as water, were successfully employed as nucleophiles in this transformation. By using isopropanol as nucleophile, the isopropoxy derivative 3ae was obtained with the highest $e e$, though the competitive formation of $\mathbf{2 a}$ took place in a small amount. As expected, alkyl-substituted alkyne 1g led to lower enantioselectivities (entries 14, and 15). Gratifyingly, oxygenfunctionalized $1 \mathrm{H}$-indenes 3 can be obtained as a single enantiomer by recrystallization (entries 1, 5-6, 8-9, 12-13, and 16-17). Moreover the absolute configuration of product 3ha was determined to be $R$ by using single crystal X-ray diffraction, ${ }^{[23]}$ and the rest were assigned by analogy.

Table 3. Gold(I)-catalyzed enantioselective synthesis of oxygenfunctionalized $1 \mathrm{H}$-indenes $3^{[a]}$

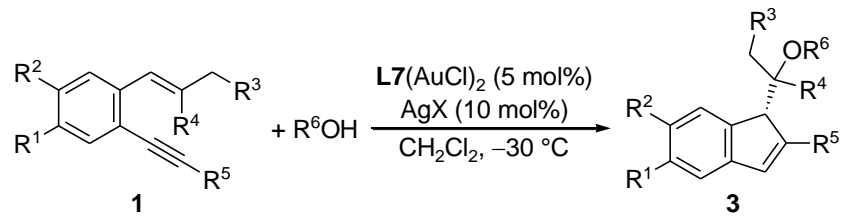

\begin{tabular}{lllllllllll}
\hline Entry & $\mathbf{1}$ & $\mathrm{R}^{1}$ & $\mathrm{R}^{2}$ & $\mathrm{R}^{3}$ & $\mathrm{R}^{4}$ & $\mathrm{R}^{5}$ & $\mathrm{R}^{6}$ & $\mathbf{3}$ & $\begin{array}{l}\text { Yield } \\
\left.[\%]^{[b]}\right]\end{array}$ & $\begin{array}{l}e e \\
{[\%]^{[\mathrm{c}]}}\end{array}$ \\
\hline 1 & $\mathbf{1 a}$ & $\mathrm{H}$ & $\mathrm{H}$ & $\mathrm{H}$ & $\mathrm{Me}$ & $\mathrm{Ph}$ & $\mathrm{Me}$ & 3aa & 99 & $88(>98)$ \\
2 & $\mathbf{1 a}$ & $\mathrm{H}$ & $\mathrm{H}$ & $\mathrm{H}$ & $\mathrm{Me}$ & $\mathrm{Ph}$ & $\mathrm{H}$ & $\mathbf{3 a b}$ & 93 & 86 \\
$3^{[\mathrm{d}]}$ & $\mathbf{1 a}$ & $\mathrm{H}$ & $\mathrm{H}$ & $\mathrm{H}$ & $\mathrm{Me}$ & $\mathrm{Ph}$ & $\mathrm{Et}$ & $\mathbf{3 a c}$ & 88 & 81 \\
$4^{[\mathrm{d}]}$ & $\mathbf{1 a}$ & $\mathrm{H}$ & $\mathrm{H}$ & $\mathrm{H}$ & $\mathrm{Me}$ & $\mathrm{Ph}$ & allyl & 3ad & 94 & 80 \\
$5^{[\mathrm{d}]}$ & $\mathbf{1 a}$ & $\mathrm{H}$ & $\mathrm{H}$ & $\mathrm{H}$ & $\mathrm{Me}$ & $\mathrm{Ph}$ & $i-\mathrm{Pr}$ & $\mathbf{3 a e}$ & $72^{[\mathrm{e}]}$ & $92(98)$ \\
6 & $\mathbf{1 b}$ & $\mathrm{H}$ & $\mathrm{F}$ & $\mathrm{H}$ & $\mathrm{Me}$ & $\mathrm{Ph}$ & $\mathrm{Me}$ & $\mathbf{3 b a}$ & 93 & $82(>98)$ \\
7 & $\mathbf{1 b}$ & $\mathrm{H}$ & $\mathrm{F}$ & $\mathrm{H}$ & $\mathrm{Me}$ & $\mathrm{Ph}$ & $\mathrm{H}$ & $\mathbf{3 b b}$ & 88 & 86 \\
8 & $\mathbf{1 c}$ & $-\mathrm{OCH}_{2} \mathrm{O}-$ & $\mathrm{H}$ & $\mathrm{Me}$ & $\mathrm{Ph}$ & $\mathrm{Me}$ & $\mathbf{3 c a}$ & 98 & $84(>98)$
\end{tabular}

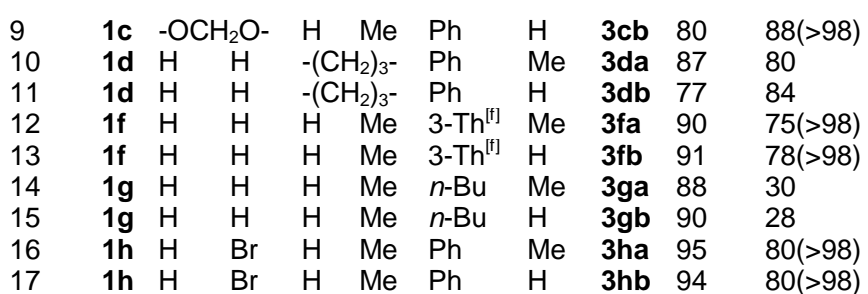

[a] Reactions conducted using $0.3 \mathrm{mmol}$ of $o$-(alkynyl)styrene derivative 1, 30 equiv. of nucleophile, AgOTs as silver salt with $\mathrm{ROH}$ and $\mathrm{AgSbF}_{6}$ with $\mathrm{H}_{2} \mathrm{O}$, in $\mathrm{CH}_{2} \mathrm{Cl}_{2}(1.2 \mathrm{~mL})$ at $-30{ }^{\circ} \mathrm{C}$ for $2-4$ days. [b] Yield of isolated product based on starting material 1. [c] Determined by HPLC analysis, see Supporting Information; in brackets ee after recrystallization. [d] Reaction conducted at $-20^{\circ} \mathrm{C}$. [e] $12 \%$ of $\mathbf{2 a}$ was also formed. [f] 3-Thienyl.

In conclusion, we have developed an asymmetric gold-catalyzed cycloisomerization or alkoxycyclization of $o$-(alkynyl)styrenes that provides enantiomerically-enriched functionalized $1 H$-indene derivatives in high yields and with $e e$ values up to $92 \%$, that can be improved to $>98 \%$ after a simple recrystallization. The combined catalytic system consisting of a gold complex with the atropisomeric electron-rich ligand 3,5-xylyl-MeOBIPHEP and silver salts efficiently promotes this enantioselective cyclization under mild conditions. It should be also remarked that the reactions here reported represent the first examples of metal catalyzed cyclizations of $o$-(alkynyl)styrenes through a 5-endo-dig mechanism. o(Alkynyl)styrenes had been widely used as precursors of naphthalene derivatives and so this work further expands the utility of these starting materials demonstrating its ability as simple precursors of (enantiopure) indenes.

\section{Experimental Section}

General procedure for the gold(I)-catalyzed enantioselective synthesis of $\mathbf{1 H}$-indenes 2 and $3: \mathrm{AgSbF}_{6}(10 \mathrm{~mol} \%, 5.1 \mathrm{mg})$ or AgOTs $\left(10 \mathrm{~mol} \%, 8.4 \mathrm{mg}\right.$ ) was added to a solution of $\mathbf{L 7}(\mathrm{AuCl})_{2}(5$ $\mathrm{mol} \%, 17.4 \mathrm{mg}$ ) in dry $\mathrm{CH}_{2} \mathrm{Cl}_{2}$ and the reaction mixture was stirred 510 minutes and cooled to $-30{ }^{\circ} \mathrm{C}$ or $-20{ }^{\circ} \mathrm{C}$ (see Tables 2 and 3 for the suitable $\mathrm{Ag}$ salt and temperature for each substrate). The nucleophile (30 equiv., $9 \mathrm{mmol}$ ), when appropriate, was added, followed by a solution of the corresponding o-(alkynyl)styrene derivative $1(0.3 \mathrm{mmol})$ in dry $\mathrm{CH}_{2} \mathrm{Cl}_{2}$. The resulting reaction mixture was stirred until complete disappearance of starting material $\mathbf{1}$, as monitored by TLC or GC-MS. The mixture was diluted with hexanes and filtered through a pad of silica gel, solvent was removed and the crude mixture was purified by flash chromatography on silica gel using mixtures of hexane and EtOAc as eluents. The corresponding $1 \mathrm{H}$-indenes $\mathbf{2}$ or $\mathbf{3}$ were isolated in the yields and enantioselectivities reported in Tables 2 and 3.

Received: ((will be filled in by the editorial staff))

Published online on ((will be filled in by the editorial staff))

Keywords: indenes - gold - C-C coupling - asymmetric catalysis . cyclization

[1] A. Korte, J. Legros, C. Bolm, Synlett 2004, 2397-2399, and references therein.

[2] See, for instance: a) J. Barberá, O. A. Rakitin, M. B. Ros, T. Torroba, Angew. Chem. 1998, 110, 308-312; Angew. Chem. Int. Ed. 1998, 37, 296-299; b) J. Yang, M. V. Lakshmikantham, M. P. Cava, D. Lorcy, J. R. Bethelot, J. Org. Chem. 2000, 65, 6739-6742.

[3] For reviews, see: a) H. G. Alt, A. Köppl, Chem. Rev. 2000, 100, 1205-1221; b) R. Leino, P. Lehmus, A. Lehtonen, Eur. J. Inorg. Chem. 2004, 3201-3222. 
[4] For recent papers, see: a) D. Zhang, Z. Liu, E. K. Yum, R. C. Larock, J. Org. Chem. 2007, 72, 251-262; b) H. Tsukamoto, T. Ueno, Y. Kondo, Org. Lett. 2007, 9, 3033-3036; c) S. Guo, Y. Liu, Org. Biomol. Chem. 2008, 6, 2064-2070; d) H.-P. Bi, L.-N. Guo, F.-R. Gou, X.-H. Duan, X.-Y. Liu, Y.-M. Liang, J. Org. Chem. 2008, 73, 4713-4716; e) M. Tobisu, H. Nakai, N. Chatani, J. Org. Chem. 2009, 74, 5471-5475; f) S. Yang, Z. Li, X. Jian, C. He, Angew. Chem. 2009, 121, 4059-4061; Angew. Chem. Int. Ed. 2009, 48, 3999-4001; g) S. Ye, K. Gao, H. Zhou, X. Yang, J. Wu, Chem. Commun. 2009, 5406-5408; h) X. Zhu, C. Mitsui, H. Tsuji, E. Nakamura, J. Am. Chem. Soc. 2009, 131, 13596-13597.

[5] a) T. Nishikata, Y. Kobayashi, K. Kobayshi, Y. Yamamoto, N. Miyaura, Synlett 2007, 3055-3057; b) T. Nishikata, S. Kiyomura, Y. Yamamoto, N. Miyaura, Synlett 2008, 2487-2490.

[6] F. Zhou, M. Yang, X. Lu, Org. Lett. 2009, 11, 1405-1408.

[7] Related Pd or Rh catalyzed asymmetric synthesis of 1-indenols from acylboronic acids and internal alkynes were also described: a) $\mathrm{M}$. Yang, X. Zhang, X. Lu, Org. Lett. 2007, 9, 5131-5133; b) R. Shintani, K. Okamoto, T. Hayashi, Chem. Lett. 2005, 34, 1294-1295.

[8] For the synthesis of enantioenriched indene derivatives from nonracemic starting materials, see: a) K. R. Romines, K. D. Lovasz, S. A. Mizsak, J. K. Morris, E. P. Seest, F. Han, J. Tulinsky, T. M. Judge, R. B. Gammill, J. Org. Chem. 1999, 64, 1733-1737; b) P. Dubé, F. D. Toste, J. Am. Chem. Soc. 2006, 128, 12062-12063.

[9] Tungsten-catalyzed 6-endo cyclizations: a) K. Maeyama, N. Iwasawa, J. Org. Chem. 1999, 64, 1344-1346; b) T. Miura, N. Iwasawa, J. Am. Chem. Soc. 2002, 124, 518-519.

[10] Rhodium- and palladium-catalyzed 6-endo cyclizations: J. W. Dankwardt, Tetrahedron Lett. 2001, 42, 5809-5812.

[11] Platinum-catalyzed 6-endo cyclizations: a) B. Martín-Matute, C. Nevado, D. J. Cárdenas, A. M. Echavarren, J. Am. Chem. Soc. 2003, 125, 5757-5766; b) V. Mamane, P. Hannen, A. Fürstner, Chem. Eur. J. 2004, 10, 4556-4575. See also reference [10].

[12] Gold-catalyzed 6-endo cyclizations: T. Shibata, Y. Ueno, K. Kanda, Synlett 2006, 411-414. See also reference [10]. A related cycloisomerization of enyne arene-chromium complexes has also been reported: C. Michou, S. Liu, S. Hiragushi, J. Uenishi, M. Uemura, Synlett 2008, 1321-1324

[13] Ruthenium-catalyzed 6-endo cyclizations: H.-C. Shen, S. Pal, J.-J. Lian, R.-S. Liu, J. Am. Chem. Soc. 2003, 125, 15762-15763.

[14] Liu and co-workers have reported the ruthenium-catalyzed cycloisomerization of $2^{\prime}, 2^{\prime}$-disubstituted $o$-(ethynyl)styrenes to afford, 2 -alkenyl- $1 H$-indenes as major adducts. The reaction is proposed to occur through a cascade process initiated by 5 -endo cyclization of the initially formed ruthenium-vinylidene species followed by a "methylenecyclopropane-trimethylenemethane" rearrangement: R. J. Madhushaw, C.-Y. Lo, C.-W. Hwang, M.-D. Su, H.-C. Shen, S. Pal, I. R. Shaikh, R.-S. Liu, J. Am. Chem. Soc. 2004, 126, 15560-15565. These results are in sharp contrast with the total selectivity to give naphthalene derivatives through a 6 -endo cyclization reaction observed with the same ruthenium catalyst when non di-substituted $o$ (alkynyl)styrenes are used as starting materials (see reference [13]).

[15] For excellent reviews on metal-catalyzed cycloisomerization reactions of enyne derivatives, see: a) E. Jiménez-Núñez, A. M. Echavarren, Chem. Rev. 2008, 108, 3326-3350; b) V. Michelet, P. Y. Toullec, J.-P. Genêt, Angew. Chem. 2008, 120, 4338-4386; Angew. Chem. Int. Ed. 2008, 47, 4268-4315.

[16] A similar result was obtained by using $5 \mathrm{~mol} \%$ of the bis(trifluoromethanesulfonyl)imidate derivative $\left[\mathrm{AuNTf}_{2}\left(\mathrm{Ph}_{3} \mathrm{P}\right)\right]$.

[17] For related mechanisms, see: a) M. R. Luzung, J. P. Markham, F. D. Toste, J. Am. Chem. Soc. 2004, 126, 10858-10859; b) L. Zhang, S. A Kozmin, J. Am. Chem. Soc.2005, 127, 6962-6963; c) A. K. Buzas, F. M: Istrate, F. Gagosz, Angew. Chem. 2007, 119, 1159-1162; Angew. Chem. Int. Ed. 2007, 46, 1141-1144; d) Y. Horino, T. Yamamoto, K. Ueda, S. Kuroda, F. D. Toste, J. Am. Chem. Soc. 2009, 131, 2809-2811.

[18] The scope of this new transformation was briefly checked by using different $o$-alkynyl styrenes 1a-h. See Supporting Information for the synthesis of racemic 1-alkenyl-1 $H$-indenes 2a-g and 1-oxygenfunctionalized- $1 H$-indenes $\mathbf{3 a a}-\mathbf{3 h b}$. In addition, we also checked the behaviour of the corresponding terminal alkyne, 2',2'-dimethyl $o$ (ethynyl)styrene, though the reaction was sluggish giving rise to decomposition products.

[19] For reviews, see: a) R. A. Widenhoefer, Chem. Eur. J. 2008, 14, 5382-5391; b) N. Bongers, N. Krause, Angew. Chem. 2008, 120 , 2208-2211; Angew. Chem. Int. Ed. 2008, 47, 2178-2181.

[20] For recent examples, see: a) A. Z. González, F. D. Toste, Org. Lett. 2010, 12, 200-203; b) R. L. LaLonde, Z. J. Wang, M. Mba, A. D. Lackner, F. D. Toste, Angew. Chem. 2010, 122, 608-611; Angew. Chem. Int. Ed. 2010, 49, 608-611, and references cited therein

[21] a) M. P. Muñoz, J. Adrio, J. C. Carretero, A. M. Echavarren, Organometallics 2005, 24, 1293-1300; b) M. J. Johansson, D. J. Gorin, S. T. Staben, F. D. Toste, J. Am. Chem. Soc. 2005, 127, 18002-18003; c) C.-M. Chao, M. R. Vitale, P. Y. Toullec, J.-P. Genêt, V. Michelet, Chem. Eur. J. 2009, 15, 1319-1323; d) C.-M. Chao, D. Veltrami, P. Y. Toullec, V. Michelet, Chem. Commun. 2009, 6988-6990. See also: L. Charruault, V. Michelet, R. Taras, S. Gladiali, J.-P. Genêt, Chem. Commun. 2004, 850-851, for a conceptually related Pt-catalyzed alcoxycyclization of 1,6-enynes.

[22] ortho-(Alkynyl)styrenes could be considered in some way as 1,5enynes. As far as we know neither the Au-catalyzed enantioselective cycloisomerization of $o$-(alkynyl)styrenes neither of 1,5-enynes has been reported. In contrast, Au-catalyzed enantioselective reactions of 1,6-enynes have been described (see references [21a,c,d]).

[23] CCDC 766525 (3ha) contains the supplementary crystallographic data for this paper. These data can be obtained free of charge from The Cambridge Crystallographic Data Centre via www.ccdc.cam.ac.uk/data_request/cif. 


\section{Chiral indenes}

A. Martínez, P. García-García, M. A.

Fernández-Rodríguez, F. Rodríguez, R.

Sanz*

Page - Page

$\mathrm{Au}(\mathrm{I})$-Catalyzed Enantioselective Synthesis of Functionalized Indenes

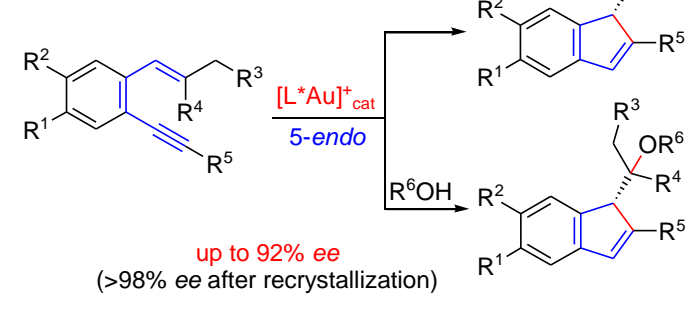

An asymmetric synthesis of functionalized $1 \mathrm{H}$-indenes from easily available ortho-

(alkynyl)styrene derivatives under mild conditions is reported. The reactions proceed through an unprecedented and selective 5-endo-dig gold(I)catalyzed cycloisomerization or alkoxycyclization, if water or an alcohol is present. The indenes are obtained in high yields and with ee values up to $92 \%$ that can be even improved to $>98 \%$ after recrystallization. 